Nations and Nationalism $\bullet(\bullet \bullet), 2016,1-19$.

DOI: $10.1111 /$ nana.12277

\title{
The nation-state in its state-istics (Belgium, 1846-1947)
}

\author{
KAAT LOUCKX \\ Department of Sociology, University of Chicago, USA \\ Center for Social Theory, Ghent University, Belgium
}

\begin{abstract}
Statistics are, as the etymology of the term suggests (state-istics), intimately connected with the construction or administration of the nation-state. This paper addresses the genesis and development of the nation-state by studying one of the main instruments that states use to 'embrace' their populations, viz. population statistics. More particularly, the paper presents a critical analysis of the conceptual and 'scientific' representations of modes of belonging to the nation-state as produced in the Belgian (Queteletian) population censuses from the mid-nineteenth until the mid-twentieth century. It is shown how the analyses of the statisticians' interests, techniques and classification schemes shed light on the various ways in which inclusion in, or exclusion from, the Belgian nation-state have been articulated in its population censuses. It is argued that these shifting interests and classification schemes also inform us about the construction and administration of the contemporary nation-state.
\end{abstract}

KEYWORDS: census, citizenship, identity, language, nation-state, statistics

\section{Introduction}

Statistics are, as the etymology of the term suggests, intimately connected with the construction or administration of the nation-state. The German Statistik, as introduced by Gottfried Achenwall and others, originally designated the 'study of the state', a scientific representation of the state, its territory and its population for administrative, governmental purposes. In the latter part of the eighteenth century, the term also appeared in English. In 1797, the Encyclopaedia Britannica described statistics as 'a word lately introduced to express a view or survey of any kingdom, country or parish'. During most of the nineteenth century, the etymology of the term 'statistics' was still very much alive: statistics meant state-istics, the empirical or scientific study of the state.

The rise of statistics and other information systems is linked with fundamental social and cultural changes that took place in that period (see, e.g., Headrick 2000). State-istics had to cover the growing need for information in the emerging 'enlightened' political regimes in Europe. Absolutist monarchs could still refer to their divine right to rule in their own personal or dynastic interests, as though these were the only interests they had to consider. In contrast, enlightened politics implied that monarchs ruled for the benefit of their subjects or citizens. Knowing what was in the interest of one's people, however, 
required a lot more information than knowing one's own personal or family interests. Since the nineteenth century, numbers and statistics have become basic parts of the bureaucratic machinery of modern states.

Ian Hacking $(1990,1991)$ has spoken of the 'avalanche of printed numbers' to characterize the rapid development of information technologies and the growing scale of statistics in the nineteenth century. He particularly refers to the United States census and its expansion. In 1790, the first census asked four questions of each household. In 1880, the tenth census posed 13,010 questions in various questionnaires addressing people, firms, farms, hospitals, churches and more. Statistical thinking has thus also been implanted in a bureaucratic machinery. Behind the rise of state-istics and the avalanche of printed numbers, as Hacking puts it, 'lay new technologies for classifying and enumerating, and new bureaucracies with the authority and continuity to deploy the technology' (Hacking 1990: 2-3). In this sense, we can say that population statistics is both a cause and a consequence of how we see our modern society (Holmberg et al. 2012; Louckx and Vanderstraeten 2015).

State-istics, however, not only provides scientific or 'objective' representations of the state of the state but also rationalizes and standardizes its object into administratively convenient formats. It may, moreover, be added that the state is well equipped to insist on treating individuals according to its proper classifications and designations. It is able to use and impose its own instruments in order to distinguish between individuals who belong and individuals who do not, to acquire from its population the resources it needs to survive, to exclude from among the beneficiaries of state largess those parts of the population deemed ineligible for benefits, and so on (Scott 1998: 82-83).

Seen from this perspective, analysing the history of statistical constructions may help us to shed light on the 'systems of thought' underlying the categories and classification schemes used by states to enumerate, to represent, to classify and to 'take care' of their respective populations (see also Urla 1993). It may help us to elucidate the ways in which the modern nation-state is indeed, to adopt Benedict Anderson's (1983) felicitous phrase, an 'imagined community'. Analysing the history of the forms and categories used in state-istics may hence shed light on the politics of membership in modern nation-states. In particular, it may clarify some of the 'banal' or 'invisible' ways in which states tend to take care of their populations (see also Billig 1995; Louckx and Vanderstraeten 2014).

In this paper, I will present a historical-sociological case study that focuses on the ways in which the modern state has come to conceive of itself as a nation-state and, more particularly, on the modifications in the definition of national identity and national citizenship in the population census. The census is commonly defined as an 'attempt to count all the people in a country at a given point in time' (Headrick 2000: 76). In the census, the statisticians typically included a range of questions about the socio-economic situation of households and their individual members. However, they also inquired into the 'nation' and its citizens (see also Anderson 1990). They also explored ways to legitimize the existence of the nation-state and to distinguish between 
members and non-members, nationals and foreigners. As Kertzer and Arel (2002: 3) argue, the census is also 'the most visible, and arguably the most politically important, means by which states statistically depict collective identities'. By tracing the ways in which the 'nation' (as idea and as community) was delineated, I hope to illuminate the tensions and conflicts that presided over the production of some basic modern state-istical concepts and categories.

I will, more particularly, present a historical-sociological analysis of the population censuses conducted in Belgium. I believe that Belgium allows for a particularly interesting case study, not only because of the specific characteristics of the Belgian nation-state, which resulted in fundamental processes of state reform during the second half of the twentieth century, but also because of the fact that the Belgian homo statisticus Adolphe Quetelet played a key role in the development of population censuses and state-istics - both nationally and internationally. Perhaps the following case study therefore also has some broader relevance. The time frame of my analysis consists of a period of about one century: from the first Belgian population census taken in 1846 until the tenth population census conducted in 1947. As we will see, it is in this time period that contemporary representations of the Belgian nation-state and its state-citizenship emerged.

My primary historical sources consist of the Belgian census reports. These reports contain a presentation of the results of the census, as well as a rather technical part that reproduces the instructions to the census takers. I will refer to these reports by the letter B followed by the year the census was taken. In order to contextualize these historical sources, I have also made use of reports of the International Statistical Congress (abbr. CPCIS), the Proceedings of the Plenary Sessions of the Belgian Chamber of Representatives (abbr. BCR) and of Belgian juridical sources, such as the Belgian Constitution and the Belgian Civil Code.

In the Belgian censuses, several items have been connected with the nationstate as such: religion, language, place of birth, and nationality. Hereafter, I first discuss the questions on religion and language and their modifications in the course of time. While language is said to have a relatively defined territorial component in the modern era (Gellner 1983; Rokkan 1999), the idea of 'one nation, one language' was also contested in Belgium. I show how language has become the source of relatively strong social and cultural cleavages within the Belgian nation-state - with the well-known tensions between its different linguistic communities in the second half of the twentieth century. Afterwards, I analyse the ways in which data about each individual's birthplace and nationality were collected and processed in the Belgian censuses. These analyses also show how definitions of national identity correspond with changing stateistical interests in managing and controlling migration in a world characterized by increasing transnational mobility. In the final section, I conclude with a discussion of the historical and contemporary relevance of the distinction between insiders and outsiders, or nationals and foreigners for the project of nationbuilding within Belgium. 


\section{Religion and language}

In early nineteenth century Europe, the idea had started to gain ground that language and territory were (or had to be) inextricably linked. One more or less standardized and unified language was increasingly seen as an identifying marker for a particular state; knowledge of 'its' language also became an essential requirement for social mobility in the state (see Wright 2000; Burke 2004; Edwards 2009). Peter Burke (2004: 10), for example, refers to the French priest and politician Henri Grégoire, who at the time of the French Revolution started to propagate the teaching of Standard French all over France in order to fondre tous les citoyens dans une masse nationale [melt all citizens into one national mass].

However, the nineteenth century saw not only the development of direct links between territorial and linguistic unity but, in various parts of Europe, linguistic diversity also gained ground. Several 'other' languages used, or formerly used, within the territory of the state were able to be revived. Examples include the Frisian, Norwegian or Finnish movements. It was also in the context of this struggle between unifying forces and, to some extent, diversifying forces, that Belgium was founded in 1830.

At the Congress of Vienna in 1814, the Southern Netherlands had been united with the Northern Netherlands to form the United Kingdom of the Netherlands. But a range of cultural differences created obstacles for the unification policies of King William I. Especially religious matters (the Protestant North vs. the Catholic South) were important in the conflict preceding the separation. William's pronounced Protestantism and his attempts to curtail Catholic influence on education aroused much opposition among the Catholic population in the Southern part of the United Kingdom of the Netherlands (Kennedy 2010: 127). The language issue also played a role in the conflict. William's language policy aimed at uniting the two regions under a common Dutch language. But the strict language policy he imposed in order to 'dutchify' - and in this way also to 'defrenchify' - public life was highly contested by the social elite in the South, which demanded freedom of language choice (Witte and Van Velthoven 2011: 55).

After the Belgian Revolution, the new Constitution guaranteed freedom of language choice (Servais et al. 1933: 5). In practice, however, French was perceived as the more prestigious language. Although the majority of the Belgian population was Flemish-speaking, French quickly replaced Dutch in all official domains and official functions (see, e.g., Dubois 2005; Wils 2009). ${ }^{1}$ French was not only the language of enlightenment, progress and modernity; it was above all also a symbol for the national struggle for independence (Vandenbussche 2007). Catholicism also served to underline the identity of the new Belgian state. While the role of religion in education had been under attack under King William I, the Catholics were now able to secure financial support of the state for the Church and Catholic education. In the second half of the nineteenth century, however, this support would give way to sharp 
conflicts between the Liberals and Catholics (Lory 1979; Stengers and Gubin 2002: 75-101).

The first Belgian census inquired into religious adherence. ${ }^{2}$ It was concluded that almost the entire Belgian population adhered to Catholicism; only a small number adhered to another religion, while some individuals had refused to answer the question. After 1846, no Belgian census again included this question. This item was contested, especially by the Liberals, as it was regarded as a violation of people's privacy (e.g., BCR 12 January 1847: 457; see also Bracke 2008). ${ }^{3}$ At the same time, however, the Liberals pressed for information about religious professionals and their work in schools and hospitals. They aimed at an overview of the numerical strength of the 'sacred militia' of the Catholic Church. Despite much protest from the Catholics, from 1856 to 1947, the census included a special count of the members and activities of all religious orders and congregations (Tihon 1976; Vanderstraeten 2007). The item on religion did not return in the population census, although the 1860 International Statistical Congress formally recommended inquiring into the religious adherence of all inhabitants (Levitan 2011; see also Thorvaldsen 2014).

With the exception of the 1856 census, all censuses taken between 1846 and 1947 included language items. ${ }^{4}$ In the first Belgian census, the statisticians defined language as one of the most enduring distinguishing features of people or populations (B 1846: XXXVI). ${ }^{5}$ The census included, more particularly, a question on the habitually spoken language [la langue parlée habituellement] (B 1846: LV). No options were specified; the respondents could fill in any language. In the summary tables with the results, the statisticians grouped the data in the following categories: French or Walloon (which they considered to be a dialect of Standard French), Flemish or Hollandish (which was considered to be a dialect of Flemish), German, English, and other languages (B 1846: XXXVII). ${ }^{6}$ The figures presented made clear that French or Flemish were almost the majority languages in Belgium. There were more Flemish than French speakers - with a proportion of about 4 to 3 - while German was spoken in parts of the Belgian province of Luxembourg. The statisticians added that all other languages were only used by a small group of migrant workers and merchants, and by foreigners who were only temporarily residing in Belgium (B 1846: XXXVII).

In the 1846 census report, the Belgian statisticians also invoked the authority of 'philologists' to refer to the unifying force of a common, standardized language. In their view, the line of demarcation between the French- and Flemish-speaking populations was a symptom of more fundamental social divisions within the Belgian state [le peuple belge se trouve divisé sous le rapport du langage parlé] (B 1846: XXXVI).

Without any explanation, the 1856 census questionnaire included no item about language. But, as of 1866, new attempts were made to inquire into the linguistic identity of the population of the Belgian nation-state. The statisticians also rephrased the language item. In 1866, the aim was no longer to 
collect data about the variety of languages spoken within the country. Instead, the statisticians started to collect information about the ability of citizens to speak French, Flemish or German. The statisticians seemed to distance themselves from the idea of 'one state, one nation, one language'. They now depicted the most commonly spoken languages in Belgium - French or Walloon, Flemish or Hollandish, (Lower) German or Luxembourgish - as the state's national languages (see, e.g., B 1866: XII; B 1880: XLIX; B 1890: CL; B 1900: CLXX).

From 1866 onwards, individuals were more particularly asked to declare which and how many of the Belgian national languages they habitually used. Hence, the language data could be used to determine the strengths of the different monolingual blocs within the state - the statisticians also started to show interest in the incidence of bi- and trilingualism among the Belgian population (B 1866: XXI-XXII; B 1880: XXV; B 1890: XXXV-XXXVIII; B 1900: XXXIX-XLV; B 1910: 105, 203; B 1920: 16-17). This interest was politically and state-istically motivated. The emphasis on bi- and trilingualism could serve to distinguish Belgium from France, whose assimilatory Frenchonly policy ruled out all regional languages. This official 'presentation of self' could strengthen the Belgian identity and protect the nation-state against France's expansion plans (see Vogl and Hüning 2010; Hüning 2013). But it also became important for the Flemish movement in the second half of the nineteenth century, when a bilingual status for Flanders was pursued in order to counter French-language dominance (see Witte and Van Velthoven 2011: $63,222)$.

At the moment that the statisticians started focusing on the ability to speak one of the Belgian national languages, they also started to refrain from processing data on the use or knowledge of 'foreign' languages, such as English, Italian or Latin. People unable to speak any of the national languages also did not have to specify the languages they were able to speak; they were simply classified in the residual category of 'inhabitants who don't speak one of the three languages' (see, e.g., B 1866: XLII; B 1880: LXXXV; B 1890: CXXII; B 1900: CLVI; B 1910: 105).

By the end of the nineteenth century, new language laws had started to regulate the use of Flemish in the courts, the administration and the state secondary schools. Along with the extension of suffrage, more rights were granted to the Flemish-speaking population (see also Wright 2000: 22; Brubaker 2013: 13). ${ }^{8}$ In 1898, the Law on Equality was introduced; French and Flemish were now acknowledged as co-equal official languages. Political disagreement over the use of languages continued, however. Segments of the French-speaking elite were concerned that the new rules could result in Belgium becoming a bilingual country, with French and Flemish being recognized as official languages everywhere (Witte and Van Velthoven 2011: 81). In 1921, a compromise established territorial monolingualism in Flanders and Wallonia, except for Brussels, which became an officially bilingual enclave in a monolingual Flanders (Arel 2002: 106). 
As of 1910, while continuing to ask about the national languages spoken, the Belgian census takers also asked those who named more than one language a second question, namely, which one they used most frequently (see, e.g., B 1910: 4; B 1920: 26; B 1930a: 41; B 1947: 70). This supplementary question was added on the demand of Flemings, who wanted to identify bilingual individuals who still retained Flemish as their main language (Arel 2002: 106). But in the summary census tables about the linguistic state of the nation, bi- or trilingual inhabitants were counted two or three times. For example, Flemish-speaking inhabitants who also had knowledge of French were added to both the Flemish- and the French-speaking population (e.g., B 1910: 203; B 1920: 63; B 1930b: 14). Much opposition crystallized around this strategy, especially in the Flemish-speaking part of the country. As Flemings were more likely to be bilingual than Walloons (among other reasons because secondary education took place solely in French on the entire Belgian territory until the late nineteenth century), the census data were believed to overestimate the number of French speakers (see Levy 1960; Verdoodt 1983). Opposition was also raised because in political discussions the numbers for Brussels were not used to underline the bilingual character of the capital, but rather to focus upon the high proportion of French-speaking inhabitants. In this context, bilingualism was now increasingly viewed as a transitional stage from Flemish- to French-speaking (see also Van Velthoven 1987; O'Neill 2000; Haarman 2012).

Already in the 1880 census, the statisticians had started to express their doubts about the completeness and correctness of the language count (B 1880: LXXXIII). Census takers were instructed to double-check the responses in order to ascertain if bilingual Flemings were neglecting to identify themselves as bilingual (B 1890: CXXVIII-CXXIX). Fines were imposed to penalize individuals who attempted to make false declarations (B 1890: CXI, CXXIX; B 1900: CXXXVII; B 1910: 88). However, the statisticians did not believe that these interventions had the hoped-for results. In the early twentieth century, they explicitly pointed at the increase of false language declarations to account for the declining number of bilingual Flemings (e.g., B 1910: 203-204; B 1920: 64).

Another series of statistical interventions is also worth mentioning. Throughout the entire period under study, the collection of data on the language skills of (very) young children and dumb people [muets] caused concern. In the 1846 census, the rule was put forward that the language spoken in each family had to be registered even for all newborns and dumb persons (B 1846: $\mathrm{L}, \mathrm{LV}, \mathrm{LXIX)}$. In the 1866 census, a residual category was created for the deaf-and-dumb [sourds-muets], while the language(s) of the parents had to be entered for all children who were not yet able to speak (B 1866: XLII). In the 1880 census, the residual category for the deaf-and-dumb again disappeared; dumb people who knew one of the national languages were now considered to be able to speak this language. At the same time, it was now argued that children over two years of age were considered to be able to speak, while 
children below that age were not (B 1880: XXV, LXXXV). In the 1890 census, the census takers again listed the language of the parents for all the children who were not yet able to speak (B 1890: IV). ${ }^{9}$ As of 1900 , however, they returned to the rule applied in 1880 - and thus re-created a category for children who were not yet able to speak a language but were in the process of learning one (e.g., B 1900: V; B 1910: 4; B 1920: 16; B 1930a: 41; B 1947: 106). For the dumb, the statisticians stuck to the rule that these people were considered able to speak the national language they habitually used to express their ideas [dont ils se servent habituellement pour exprimer leurs idées] (e.g., B 1890: CXXII; B 1900: CLVI; B 1910: 105; B 1947: 99).

Some more systematic observations may be added. Despite the focus on the langues parlées, the census reports show many traces of the impact of standard written languages on national identity constructions in Belgium. The "nationalization' of the languages commonly used in Belgium depended on processes of standardization and homogenization. In 1880, the census takers were explicitly directed to consider Walloon as a variety of French, Dutch or Hollandish as varieties of Flemish, and Lower-German or Luxembourgish as varieties of German (see, e.g., B 1880: LXXXV; B 1890: XXXV; B 1910: 44, 105) ${ }^{10}$ From the 1890 census onwards, only French, Flemish and German appeared as headings in the census reports (see, e.g., B 1890: LXXXIII, LXXXV; B 1900: CV; B 1910: 45). This homogenization did not cause problems in Wallonia. Throughout the entire period under study, the Romance varieties spoken in Wallonia were regarded as dialects of the prestigious French language. In the whole French language area, local dialects had been in decline since the sixteenth century, i.e. since the development of standard French out of the dialect of the Ile de France (Nadeau and Barlow 2006). But the sociolinguistic situation was different in Flanders, where the opposition to a joint Flemish-Dutch standard language was at least in part motivated by the fear of possible Protestant influence from the Netherlands.

By the early twentieth century, however, the Flemish movement had become more oriented towards the Netherlands. The identification of the Flemish varieties in Belgium with the Dutch of the Netherlands was a way to enhance the prestige and thus strengthen the position of Dutch (Flemish) against French in Belgium (Vogl and Hüning 2010: 238). In 1947, the label Flemish was replaced by that of Dutch in the Belgian population census (e.g., B 1947: 106-112). In the eyes of the state and its state-istics, Flemish was now a dialect of Dutch (while the Romance varieties spoken in Wallonia had always been viewed as dialects of standard French).

In 1932, new language legislation specified that the results of the language count had to be used to determine the 'language regime' of local municipalities. It held a provision that municipalities with a linguistic minority of at least 30 per cent were to be governed bilingually and that, should the minority become the majority, the linguistic status of the municipality was to change accordingly (see B 1947: 80, 82). In Flanders, the results of the count were highly contested, as several heretofore monolingual Flemish 
municipalities now were to become legally bilingual. The 'marginalization' of the Flemish language in Brussels was also decried (Kertzer and Arel 2002: 31). In the Belgian Chamber of Representatives, the results of the language census were repeatedly called into question. It was, moreover, argued that the census was not a referendum (BCR 14 October 1947: 5; see also B 1947: 70).

In this period, pressure was also built for the establishment of a constitutional language border between the two linguistic regions of Belgium. Many local authorities in Flanders opposed any new language census. Owing to this political conflict, the government postponed the 1957 census (see, e.g., Levy 1960; Louckx 1982; Verdoodt 1983). The next census was conducted in 1961, but language questions were now dropped from the census, or any state-funded activity. Shortly afterwards, the territorial language border was established constitutionally (1962-1963). By officially linking territory with language, Belgium was paving the way towards federalism.

In the course of the nineteenth and twentieth century, different ideas and definitions of the nation-state have developed within Belgium. As in most other nation-states, a common and uniform language was regarded as an identifying marker that could hold all the inhabitants of the state together (see, e.g., Arel 2002; Edwards 2009; Malesevic 2013). Over time, however, the Belgian state has become subdivided into separate language territories. The official demarcation of these language territories was not simply a solution to a language conflict; it also followed from and reinforced the nineteenthcentury idea of 'one state, one nation, one language'. Far from merely reflecting what is 'out there', the census also became a mechanism of identity formation. The census became a political battleground, seized by insurgent political forces to create their own construction of social reality (Urla 1993: 837; Kertzer and Arel 2002: 25). The history of the Belgian language census and its representations of the nation-state sheds light on the identity problems with which the Belgian state was faced. As we have seen, these state-istics did not simply provide information about the state of the nation-state; they also created a dynamic that came to threaten the very existence of the Belgian nation-state.

\section{Place of birth and nationality}

The Belgian state originated at a time when states were ideally linked to one language (and one religion) and when languages had - at least in theory - to be standardized and uniform and to serve as identifying markers holding all the members of the nation-state together. But not only was linguistic unity linked with national unity at that time - the concept of citizenship also arose, together with the concept of the nation-state. In the course of the nineteenth century, the rights conferred upon citizens started to grow in number and substance. But these rights were increasingly confined to nationals. An 
increasing delimitation of national citizenries took place. Citizenship came to mean membership in the nation-state (see Hobsbawn 1990; Brubaker 1992; Torpey 2000).

After the Belgian Revolution of 1830, the Belgian Civil Code and the Belgian Constitution established legal Belgian citizenship. On the basis of these laws, citizenship could be automatically attributed (by the state to the individual), acquired (by the individual through procedures prescribed by the state) and withdrawn (from the individual by the state authorities). ${ }^{11}$ Notwithstanding several adaptations, the core principles of this legislation remained the same until the early twentieth century. After the First World War, protectionism prevailed and greater restrictions in granting Belgian citizenship to foreigners were imposed (Caestecker 1999; Foblets et al. 2013).

Belgian citizenship was in principle granted at birth. The dominant Belgian practice built upon the principle of jus sanguinis paterni [right of blood in the paternal line]: a child whose father had Belgian citizenship automatically acquired Belgian citizenship, irrespective of the place of birth. This mode of attribution was legitimized by the conviction that citizenship could not simply follow from 'accidentally' having been born in Belgium, but had to be seen as the consequence of family or blood ties, as the heritage of a community, which is made up of people who together form a sovereign nation. But the principle of jus soli [right of soil] was also introduced: a child born in Belgium to non-Belgian parents, for example, could acquire the Belgian citizenship if certain requirements (mainly pertaining to age and residence) were fulfilled. The principle of 'one family, one citizenship' was also stressed (de Hart 1999: 190; Auslander 2001: 144). For instance, a foreign woman who married a Belgian man took the citizenship of her husband and so did the children born in wedlock. Inversely, a Belgian woman who married a foreigner took the status of her foreign husband (Weil 2005). Belgian citizenship could moreover be lost by individuals who voluntarily acquired the nationality of a foreign state, voluntarily served in a foreign army, or settled abroad and did not show any evidence of an intention [animus] to return to Belgium.

However, despite the elaboration of the politico-legal institution of Belgian citizenship, and despite its symbolic importance for the new state, the Belgian census did not include any question about legal nationality until the end of the nineteenth century (B 1890). In the first censuses, the census takers were even explicitly directed not to take legal nationality into account. The census takers were instructed to gather data about all those present in the household - quelle que soit leur nationalité (B 1866: XXXI). ${ }^{12}$ The Belgian statisticians used another variable to provide a more detailed overview of the modes of membership in the nation-state. Instead of legal nationality, they focused on people's place of origin or birth (e.g., B 1846: XXXVIXXXVII; B 1856: XIX, XLVIII, XLIX; B 1866: 19; B 1880: XXI; B 1890: XXIII-XXIX).

(C) The author(s) 2016. Nations and Nationalism (C ASEN/John Wiley \& Sons Ltd 2016 
In the view of the Belgian statisticians, the question about the place of origin or birth enabled them to monitor people's 'movements' on the territory of the Belgian state (B 1846: XXXV; see also B 1856: XVIII; B 1866: XX). Initially, the statisticians showed a strong interest in both intra- and international movements (B 1846: XXV; B 1856: XIX; B 1866: 18; B 1880: XXII). But in the last decades of the nineteenth century, their state-istical interest shifted almost exclusively towards international migration. At that time, they also started to speculate on the motives the growing number of migrants might have. In their opinion, economic motives dominated. The statisticians argued that most étrangers [foreigners] living on Belgian territory had left their country of origin to find fortune in Belgium. They added that it was not likely that these étrangers would return to their country of origin or birth (e.g., B 1890: XXXIII; B 1900: XXXVII).

As of 1880, the census reports started to include longitudinal overviews of population movements to and from Belgium. The table drafted by the statisticians divided the growing number of foreigners residing on Belgian territory on the basis of their place of birth, but the table's title promised an overview par nationalité (B 1880: XXIII). Based on census data from a number of other countries, such as France, Germany, the United States and Great Britain, the 1880 census report also tried to provide an overview of the number of 'Belgians' living abroad. But in an explanatory note, the statisticians clarified that the term 'Belgians' referred solely to people born in Belgium and not to people with the Belgian nationality in the legal sense of the word (B 1880: XXIV). Although the law primarily distinguished between citizens and noncitizens on the basis of blood ties, the official state-istics show how territorial criteria predominated over legal criteria in distinguishing between nationals and foreigners. The Belgian nation-state was imagined as a community of birth, of native-born citizens.

Six decades after Belgium's independence, the 1890 census was the first to include an item on the legal nationality status of the inhabitants. According to the statisticians, the inclusion of this item constituted a national and international interest [un intérêt national et international]; they also mentioned that they followed the example of several other states (B 1890: IV-V). At the political level, moreover, the extension of male suffrage and of social rights also led to an increased interest in legal nationality and turned legal nationality into an important marker of national belongingness (see Caestecker 2010: 373-374). In the census report, the statisticians now made clear that only individuals who possessed Belgian nationality status could be identified as Belgians. Inversely, foreigners were defined as individuals who did not possess Belgian nationality status (B 1890: LXXXIII; B 1910: 49). However, the item on the legal nationality status did not replace but supplemented that on people's place of birth or origin. Different understandings of belongingness were thus introduced. The difference was also stressed on many occasions; in the instructions to the census takers, the statisticians repeatedly insisted that nationality declarations needed to be 
made in conformance with the legal definition of nationality (e.g., B 1900: LXXXIV; B 1910: 29).

The presentation of the data on national citizenship in the census reports also shows the lasting concern of the statisticians regarding the increase of the number of migrants. In fact, the Belgian statisticians often presented tables in which the data on nationality and place of birth were compared or crossed. In 1890, for example, the statisticians started to focus on the countries of birth and of nationality of the largest number of foreigners on Belgian territory (e.g., B 1890: XXXV; see also B 1900: XXV; B 1910: 192; B 1920: 59). As of 1900, they also focused on the balance between migration to and from Belgium (e.g., B 1900: XV; B 1910: 183; B 1930c: 53). It was, for example, noted in the 1900 census report that the emigration was higher than the immigration. While the growth of the population living on Belgian territory was mainly 'homemade', Belgium was also able to contribute considerably to the so-called international circulation of humanity (B 1900: XV). ${ }^{13}$

As of 1890 , the statisticians also devoted substantial parts of the census reports to the presentation and interpretation of cross-tabulations in which citizenship categories appeared. They distinguished, for example, between Belgians born in Belgium, Belgians born abroad, individuals of foreign nationality residing in Belgium and born in Belgium, and foreigners residing in Belgium but born outside of Belgium. ${ }^{14}$ They not only compared the size of the different citizenship categories, but also discussed changes over time (or the lack thereof) and speculated about push and pull factors, such as economic opportunities and urbanization (e.g., B 1890: XXXIV; B 1900: XXXVI-XXXVIII; B 1910: 195-198; B 1920: 59; B 1930c: 48, 54-55, $58-59,72)$. Indirectly, these tables allowed the identification of individuals who might qualify for naturalization procedures. Moreover, the tables could be used to identify groups that 'lagged behind' in certain respects, leading to demands for further remedial policies by the state (see Kertzer and Arel 2002: 30).

In the same context, the statisticians also started to pay attention to gender differences (e.g., B 1900: XXXV; B 1910: 195; B 1920: 59). For example, they linked the finding that most immigrants were men with economic factors. Male immigrants were depicted as economic players, who migrated to Belgium to find jobs (B 1890: XXXIII; B 1900: XXXVII; B 1910: 197). The high number of women from the neighbouring countries living in Belgium was attributed to the demand for household workers in Belgium (B 1890: XXXIII; B XXXV; B 1910: 195; B 1920: 59; B 1930c: 77). The high proportion of women born in Belgium to foreign parents was said to be the counterpart of men's higher mobility. Men migrated more easily not only for economic reasons; they often also had to return to their country of legal nationality to fulfil their military service (B 1900: XXXVII; B 1910: 197). The higher proportion of women among the Belgians born abroad was linked with the nationality legislation: women born to foreign parents could become Belgian by marrying a Belgian, 
while men could less easily lose their foreign nationality (B 1900: XXXVII; B 1910: 197).

In the interwar period, the Belgian statisticians continued to publish analyses of citizenship categories in relation to migratory movements. ${ }^{15}$ The economic recession after WWI left its traces on the migration policies. Foreigners now also needed to inform the census takers about the duration of their stay in Belgium; they also had to specify whether or not they had applied for a residence permit - thus showing their intention (or lack thereof) to stay in Belgium (see, e.g., B 1930a: 41, 47, 49; B 1947: 105106, 111-112). Interestingly, the statisticians also (again) developed an interest in intra-national migration movements. More particularly, in the 1930 census, the statisticians started to calculate emigration and immigration flows from Flanders to Wallonia (B 1930c: 51). They now took this internal division as the point of departure of their analyses at the moment that the tensions between Flemings and Walloons were running high but well before the establishment of the language border in Belgium and the regionalization of the nation-state (B 1930c: 50-52).

After the Second World War, the bureaucratic regulations regarding citizenship increased again (see also Brubaker 1992; Simon 1999). In the 1947 census, the statisticians thus asked naturalized Belgians to specify how they had acquired Belgian citizenship (B 1947: 51, 99, 106). The foreigners residing on Belgian territory on census day had to provide detailed information about their residence rights (B 1947: 67). The Second World War and the collaboration with Nazi Germany also left its traces. Individuals from whom the Belgian citizenship status had been withdrawn (and who had hence become foreigners) had to be identified separately (see B 1947: 69). Altogether, the statisticians now distinguished between no less than 13 categories of Belgian citizens, 7 categories of foreigners and 4 categories of state-less individuals (B 1947: 93).

This evolution reflects the rise of what Max Weber has called the 'rationallegal authority' within the modern state. With Michel Foucault, we might also speak of the étatisation and nationalization of membership (Foucault 1984: 302-303; see also Brubaker 2010). In the nineteenth and twentieth centuries, citizenship has become increasingly articulated as membership in nation-states - in Belgium as well as elsewhere. But the history of the statistical articulation of citizenship also shows the growing grasp of the state bureaucracy. It also shows how, parallel with the need for statistical representation was the need for control (see also Matthews 1993; Noiriel 1996; Torpey 2000). In twentieth-century Belgium, the political community has become divided into ever more categories. For the modern state, such distinctions between citizens and citizenship categories might fulfil another set of instrumental purposes. Although citizenship is still a key instrument for defining national identity, it has also become a key instrument for controlling access to particular social rights, for disciplining the national citizens, and for monitoring migration in a world characterized by increasing transnational mobility. 


\section{Conclusion}

The Kingdom of Belgium was founded in 1830. In many different ways, it has tried to establish itself as a modern nation-state. As other nineteenthcentury nation-states, it has invested much energy into integrating its members, and into defining its differences from other national communities. On the basis of analyses of one of its key instruments, viz. its state-istics, it is possible to reconstruct how the Belgian state has created its 'imagined community' (see also Anderson 1983; Desrosières 1998; Scott 1998). On the foregoing pages, I have more particularly looked at the 'nationalization' of languages and citizenship in the census and the meaning of the changes that took place in the construction of 'parameters of nation-ness and belonging' in the Belgian census.

Belgium has never been a state based on the principle of 'one state, one nation, one language' even though it was founded at a time when one state was ideally linked to one nation and one language. Its Constitution guaranteed a number of freedoms, including the freedom of language choice, but French remained the socially and culturally dominant language throughout the nineteenth and early twentieth century. In the nineteenth and twentieth centuries, however, the Flemish movement was also able to create its 'imagined community'. It gradually established itself upon the same, nineteenth-century principle of 'one state, one nation, one language'. In the second half of the last century, the pursuit of a linguistically homogeneous Flemish state has become part of Flemish mainstream politics. As I have pointed out, political conflicts over the statistical representations of this identity marker played an important role in the course of this historical process. The state-istical constructions of national identity created a reality of their own within the Belgian state. The census became itself a political tool with scientific prestige. But analyses of the printed numbers of the census reports only tell part of the story. Analyses of the various ways in which linguistic unity and national identity were counted and envisaged also shed light on the scientific or statistical premises and principles underlying the Belgian nation-state. In this setting, what was not counted was as important as what was counted.

The state-isticians also used other criteria to define and circumscribe the nation. In the first Belgian censuses, they registered people's place of birth. In this sense, they initially defined the nation as all those united by birth. In the 1890 census, they also started to record people's nationality or legal citizenship status. In the first half of the twentieth century, ever more elaborate and complex classifications of people's citizenship status had to be put to use. As we have seen, this historical shift evolved with and reflected the development of a new politics of belonging, which is characterized by the étatisation and nationalization of membership or citizenship. It both contributed to and reflected changes in the ways nationality was demarcated in this period of time. The Belgian statisticians have thus come to define the nation as the community of individuals who have received full citizenship rights from the 


\section{Belgian state, and thereby use citizenship categories to monitor the "wealth of the nation'.}

\section{Endnotes}

1 Flemish, also called 'Flemish Dutch', 'Belgian Dutch' or 'Southern Dutch' refers to any of the varieties of the Dutch language spoken in Flanders, the northern part of Belgium. Flemish is slightly different from Dutch spoken in The Netherlands, mainly in pronunciation, lexicon and expressions.

2 Quetelet had already included a question on religion in the census he had organized in the United Kingdom of the Netherlands in 1829 and the census he had conducted of the Brussels population in 1842. The 1846 census included a table comparing the numbers of Protestants, 'Israelites' and 'cultes non déclarés' of the 1829 census with the 1846 census. It was concluded that the numbers for the different categories had by and large remained unchanged, although the number of Protestants had diminished as a result of the separation (B 1846: XXXVII-XXXVIII). 3 The idea that religion was a private and not a public affair was not only a Belgian sensitivity. Questions on religion were included in the census in many countries in the mid-nineteenth century, but they were often dropped again shortly afterwards (Thorvaldsen 2014: 203; see also Blum 2002; Levitan 2011).

4 Belgium was the first to introduce this item into its census, with Prussia and Switzerland following in the 1850s (Arel 2002: 94).

5 In the second half of the nineteenth century, similar ideas prevailed at the level of the International Statistical Congress. Language was referred to as the core marker of nationality; concomitantly, language items had to be used to obtain information about the different nationalities within a state (e.g., CPCIS 1874: 11, 37-38, 43; see also Arel 2002: 95).

6 Hollandish or Hollandic is, together with Brabantian, the most frequently used dialect of Dutch language, spoken in the Netherlands. However, in the eyes of the Belgian statisticians, Hollandish was considered as a dialect of Flemish, and not as a Dutch dialect.

7 Similar ideas prevailed among other scientists, writers and politicians. The term 'nations' and 'races' were often used to describe the Flemings and Walloons (Stengers and Gubin 2002: 50-52).

8 From 1831 to 1893, in Belgium, a system of census suffrage was applied, which means that only male citizens who paid sufficient taxes or 'census' were granted the right to vote. In 1893, this system made way for universal multiple voting rights for men: supplementary votes were given to 'higher ranked' members of the community, such as landowners, educated people, etc. Universal suffrage ('one man, one vote') was introduced for men in 1918 and extended to all women in 1948. 9 As of 1890 , the statisticians also more explicitly defined what was meant by being able to speak a language (e.g., B 1890: CXXXI; B 1900: CLVI; B 1910: 105). Literacy (i.e. the ability to read and write) was not required. But people had to be capable of expressing themselves by means of this language in their daily life (B 1890: CXXXI; see also B 1900: CLVI; B 1910: 105).

10 Until the census of 1930 , the census takers were solely required to have knowledge of the most commonly spoken language of their locality (B 1846: L; B 1856: XXXVIII). Until that time, the census-questionnaires were also distributed in the language most commonly spoken in the municipality. Because of the minority position of Flemish, Flemish-speaking inhabitants often did not speak the same language as the census takers. In the Flemish movement, it was also feared that many Flemish-speaking population members were registered as French-speaking, making the country 'more French' in statistics than it was in reality (Hannes and Schmook 1981).

11 The Belgian Constitution distinguished between two types of naturalization, viz. 'ordinary' and full or state naturalization. Only individuals who gained state naturalization were allowed full political rights. Throughout the nineteenth century, both types of naturalization were rarely granted. Both procedures were also costly and complicated. To be eligible for ordinary naturalization, an individual needed to be at least 21 years of age and to have resided in Belgium for at least 
five years. State naturalization was only granted to those who had rendered 'special services to the country'. In 1881, new legislation made it easier for individuals, who were born abroad, to gain state naturalization (see also Caestecker 1999: 326, 337). Overall, it should also be kept in mind that nationality legislation changed frequently in Belgium during the period under study.

12 In 1846, the focus of the Belgian statisticians was on the de facto population, which calls for the enumeration of the actual population, as the registration of the resident population was still incomplete (B 1846: X, XLIV). After 1846, the Belgian census combined two enumeration principles: the de facto principle and the de jure principle, which focuses on the legally or habitually resident population. In 1920, the Belgian statistical authorities invoked the mass migration caused by World War I in order to legitimate their near-exclusive focus on the de jure population (B 1920: 1-3).

13 'Il est très intéressant de noter que la Belgique ne tire que de ses propres forces l'augmentation remarquable de sa population et que [...] elle fournit encore un contingent d'environ 3 par mille de ses habitants à la circulation internationale de l'humanité' (B 1900: XV).

14 The census takers also started to record more detailed information about the place of origin of foreigners. Foreigners no longer only had to inform about the country in which they were born, but also had to provide more specific information, such as municipality and province of birth (see $\mathrm{B}$ 1890: IV-V, LXXXIII; B 1900: CLVII; B 1910: 43, 107; B 1920: 21; B 1930a: 40; B 1947: 110).

15 It should, however, be added that in 1920, thus shortly after the First World War, it was only possible to organize a limited census. In 1930, the statisticians also indicated that it became difficult to establish and interpret the longitudinal data series, because the territorial borders of Belgium were redrawn after WWI (B 1930c: 74). More in particular, the German-speaking 'Eastern cantons' came to Belgium as a consequence of the 1919 Versailles Treaty.

\section{References}

\section{Source Material}

B 1846. Population. Recensement Général (15 Octobre 1846). Bruxelles: Le Ministre de l'Intérieur: 1849.

B 1856. Population. Recensement Général (31 Décembre 1856). Bruxelles: Le Ministre de l'Intérieur: 1861.

B 1866. Population. Recensement Général (31 Décembre 1866). Bruxelles: Le Ministre de l'Intérieur: 1870.

B 1880. Population. Recensement Général (31 Décembre 1880). Bruxelles: Le Ministre de l'Intérieur: 1884.

B 1890. Population. Recensement Général de 1890. Tome I. Bruxelles: Le Ministre de l'Intérieur et de l'Instruction Publique: 1893.

B 1900. Population. Recensement Général du 31 Décembre 1900. Tome I. Bruxelles: Le Ministre de l'Intérieur et de l'Instruction Publique: 1903.

B 1910. Population. Recensement Général du 31 Décembre 1910. Tome I. Bruxelles: Le Ministre de l'Intérieur: 1916.

B 1920. Population. Recensement Général du 31 Décembre 1920. Tome I. Bruxelles: Le Ministre de l'Intérieur et de l'Hygiène: 1926.

B 1930a. Population. Recensement Général au 31 Décembre 1930. Tome I. Bruxelles: Ministère de l'Intérieur: 1934.

B 1930b. Population. Recensement Général au 31 Décembre 1930. Tome II. Bruxelles: Ministère de l'Intérieur: 1936.

B 1930c. Population. Recensement Général au 31 Décembre 1930. Tome III. Bruxelles: Ministère de l'Intérieur: 1937.

B 1947. Algemene Volks-, Nijverheids- en Handelstelling op 31 December 1947. Deel 1. Brussel: Ministerie van Economische Zaken: 1949. 
Belgian Chamber of Representatives (BCR). 'Proceedings of the Plenary Sessions', Session of 12 January 1847 and Session of 14 October 1947, https://sites.google.com/site/bplenum (Last accessed 18 April 2016).

Commission Permanente du Congrès International de Statistique. 1874. Compte-Rendu des Conférences de Stockholm en 1874. Saint-Petersburg: Trenké \& Fusnot.

Servais, J. et al. 1933. Les codes et les lois spéciales les plus usuelles en vigueur en Belgique: avec des notes de concordance et de jurisprudence utiles à l'interprétation des textes. Bruxelles: Éditions Émile Bruylant.

\section{Other References}

Anderson, B. 1983. Imagined Communities. London: Verso.

Anderson, M. J. 1990. The American Census. New Haven: Yale University Press.

Arel, D. 2002. 'Language categories in censuses: backward- or forward-looking' in D. I. Kertzer, D. Arel (eds.), Census and Identity: The Politics of Race, Ethnicity, and Language in National Censuses. Cambridge: Cambridge University Press.

Auslander, L. 2001. 'Women's suffrage, citizenship Law and national identity: gendering the nation-state in France and Germany, 1871-1918' in P. Grimshaw, K. Holmes, M. Lake (eds.), Women's Rights and Human Rights. Houndsmill: Palgrave.

Billig, M. 1995. Banal Nationalism. London: Sage.

Blum, A. 2002. 'Resistance to identity categorization in France' in D. I. Kertzer, D. Arel (eds.), Census and Identity: The Politics of Race, Ethnicity, and Language in National Censuses. Cambridge: Cambridge University Press.

Bracke, N. 2008. 'Een Monument voor het Land. Overheidsstatistiek in België, 1795-1870. Ghent: Academia Press.

Brubaker, R. 1992. Citizenship and Nationhood in France and Germany. Cambridge MA: Harvard University Press.

Brubaker, R. 2010. 'Migration and membership', Journal of Interdisciplinary History 41, 1: 61-78.

Brubaker, R. 2013. 'Language, religion and the politics of difference', Nations and Nationalism 19, 1: $1-20$.

Burke, P. 2004. Languages and Communities in Early Modern Europe. Cambridge: Cambridge University Press.

Caestecker, F. 1999. 'In het kielzog van de Natie-Staat: de politiek van nationaliteitsverwerving, -verlies en -toekenning, 1830-1909', Belgisch Tijdschrift voor Nieuwste Geschiedenis 27, 3-4: $323-49$.

Caestecker, F. 2010. 'Belgisch immigratiebeheer: veranderende doelstellingen, resultaten en statistische presentaties (1861-2005)' in T. Eggerickx, J.-P. Sanderson (eds.), Histoire de la Population de la Belgique et de ses Territoires. Louvain-la-Neuve: Presses Universitaires de Louvain.

De Hart, B. 1999. 'Maria Toet en andere verhalen. De gehuwde vrouw en de constructie van de natiestaat', Tijdschrift voor Sociale Geschiedenis 25, 2: 183-206.

Desrosières, A. 1998. The Politics of Large Numbers. Cambridge MA: Harvard University Press.

Dubois, S. 2005. L'invention de la Belgique: Genèse d'un Etat-Nation 1648-1830. Brussels: Racine.

Edwards, J. 2009. Language and Identity. Cambridge: Cambridge University Press.

Foblets, M.-C., Yanasmayan, Z. and Wautelet, P. 2013. Country Report: Belgium. Florence: EUDO Citizenship Observatory.

Foucault, M. 1984. 'Le pouvoir, comment s'exerce-t-il?' in H. Dreyfus, P. Rabinow (eds.), Michel Foucault: Un Parcours Philosophique. Paris: Gallimard.

Gellner, E. 1983. Nations and Nationalism. Oxford: Oxford University Press.

Haarman, H. 2012. 'Language and ethnicity in a European context' in M. Hüning, U. Vogl, O. Moliner (eds.), Standard Languages and Multilingualism in European History, Vol. 1. Amsterdam: John Benjamins Publishing.

Hacking, I. 1990. The Taming of Chance. Cambridge: Cambridge University Press. 
Hacking, I. 1991. 'How should we do the history of statistics?' in G. Burchell, C. Gordon, P. Miller (eds.), The Foucault Effect: Studies in Governmentality. Chicago: University of Chicago Press.

Hannes, J. and Schmook, G. 1981. 'De volkstelling van 1846 en een protestbrief van H. Conscience', Tijdschrift van de VUB 22, 1: 41-61.

Headrick, D. R. 2000. When Information Came of Age. Oxford: Oxford University Press.

Hobsbawn, E. J. 1990. Nations and Nationalism since 1780. Cambridge: Cambridge University Press.

Holmberg, C., Bischof, C. and Bauer, S. 2012. 'Making predictions: computing populations', Science, Technology \& Human Values 38, 3: 398-420.

Hüning, M. 2013. 'Standardsprachenideologie. Über Sprache als Mittel zur Ab- und Ausgrenzung' in E. Besamusca, C. Hermann, U. Vogl (eds.), Out of the Box: Über den Wert des Grenzwertigen. Praesens: Wien.

Kennedy, J. C. 2010. 'Dutch political developments and religious reform' in K. Robbins (ed.), The Dynamics of Religious Reform in Northern Europe, 1780-1920. Leuven: Leuven University Press.

Levitan, K. 2011. A Cultural History of the British Census. New York: Palgrave Macmillan.

Levy, P. M. 1960. La Querelle du Recensement. Bruxelles: Institut belge de science politique.

Lory, J. 1979. Libéralisme et Instruction Primaire, 1842-1879. Louvain: Nauwelaerts.

Louckx, F. 1982. Vlamingen tussen Vlaanderen en Wallonië. Brussel: Vrije Universiteit Brussel.

Louckx, K. and Vanderstraeten, R. 2014. 'State-istics and statistics: exclusion categories in the population census (Belgium, 1846-1930)', The Sociological Review 62, 3: 530-546.

Louckx, K. and Vanderstraeten, R. 2015. 'Household and state-istics: cornerstones of society in population censuses (Belgium, 1846-1947)', Social Science History 39, 2: 201-215.

Malesevic, S. 2013. Nation-States and Nationalisms. Cambridge: Polity.

Matthews, M. 1993. The Passport Society. Boulder: Westview Press.

Nadeau, J.-B. and Barlow, J. 2006. Plus ça change: The Story of French-From Charlemagne to the Cirque du Soleil. London: Robson Books.

Noiriel, G. 1996. The French Melting Pot. Minneapolis: University of Minnesota Press.

O'Neill, M. 2000. 'Belgium: language, ethnicity and nationality', Parliamentary Affairs 53, 1: 114-34.

Rokkan, S. 1999. State Formation, Nation-Building, and Mass Politics in Europe. Oxford: Oxford University Press.

Scott, J. C. 1998. Seeing Like a State. New Haven: Yale University Press.

Simon, P. 1999. 'Nationality and origins in French statistics. Ambiguous categories', Population: An English Selection 11: 193-219.

Stengers, J. and Gubin, E. 2002. Histoire du Sentiment National en Belgique des Origines à 1918. Tome 2. Bruxelles: Édition Racine.

Thorvaldsen, G. 2014. 'Religion in the census', Social Science History 38, 1-2: 203-20.

Tihon, A. 1976. 'Les religieuses en Belgique du XVIIIe au XXe siècle', Revue Belge d'Histoire Contemporaine 7, 1-2: 1-53.

Torpey, J. 2000. The Invention of the Passport. Cambridge: Cambridge University Press.

Urla, J. 1993. 'Cultural politics in an age of statistics: numbers, nations, and the making of Basque identity', American Ethnologist 20, 4: 818-43.

Vandenbussche, W. 2007. 'Wij willen Willem weer: Het Verenigd Koninkrijk der Nederlanden als breekijzer voor een nieuwe 19de-eeuwse taalgeschiedenis' in W. Vandenbussche, G. Janssens (eds.), Taalpolitiek, Taalplanning en Taalgebruik in het 'Verenigd Koninkrijk der Nederlanden' (1814-1830). Gent: Koninklijke Academie voor Nederlandse Taal- en Letterkunde.

Vanderstraeten, R. 2007. 'Religious congregations at work - with special reference to Belgium' in G. Grace, J. O'Keefe (eds.), International Handbook of Catholic Education, Vol. 1. New York: Springer Verlag.

Van Velthoven, H. 1987. 'The process of language shift in Brussels: historical background and mechanisms' in E. Witte, H. B. Beardsmore (eds.), The Interdisciplinary Study of Urban Bilingualism in Brussels. Philadelphia: Multilingual Matters.

Verdoodt, A. 1983. Bibliographie sur le Problème Linguistique Belge. Québec: Centre international de recherche sur le bilinguisme.

(C) The author(s) 2016. Nations and Nationalism (C) ASEN/John Wiley \& Sons Ltd 2016 
Vogl, U. and Hüning, M. 2010. 'One nation, one language? The case of Belgium', Dutch Crossing. A Journal of Low Countries Studies 34, 3: 228-47.

Weil, P. 2005. 'Le statut de la femme en droit de nationalité. Une égalité tardive' in R. Kastoryano (ed.), Les Codes de la Différence, Race-Origine-Religion-France, Allemagne, Etats-Unis. Paris: Presses de Sciences Po.

Wils, L. 2009. Van de Belgische naar de Vlaamse natie. Leuven: Acco.

Witte, E. and Van Velthoven, H. 2011. Languages in Contact and in Conflict: The Belgian Case. Kalmthout: Uitgeverij Pelckmans.

Wright, S. 2000. Community and Communication: The Role of Language in Nation Building and European Integration. Toronto: Multilingual Matters. 